\title{
The Impact of Peer Group Pressure on Academic Performance of Adolescent Students: An Intervention Program to Resist Peer Pressure
}

\author{
Fadare, Ayoade Stephen, EdD ${ }^{1}$, Zarma, Hajia Asmau, $\mathrm{PhD}^{2}$, Fadare, Maria Cecilia, MA-SpEd ${ }^{3}$. \\ Bademosi, T., BTech ${ }^{4}$, Amanum, O. I, PGDPH ${ }^{5}$ \\ ${ }^{1}$ Ass. Professor, CSPEAR, Mindanao State University (Main), Marawi, Philippines- Correspondence Author \\ ${ }^{2}$ Professor, National Teachers' Institute/Open University Campus, Kaduna State, Nigeria \\ ${ }^{3}$ School Nurse \& Research Fellow, School clinic, Saint Louis College, Philippine \\ ${ }^{4}$ DTech \& Research Fellow, Jos University Teaching Hospital, Dental Surgery Department, Lamingo, Jos Plateau State \\ ${ }^{5}$ DTech \& Research Fellow, University of Medical Sciences, Ondo State, Nigeria.
}

\begin{abstract}
This study aims to explore the effect of peer group pressure on the academic performance of adolescent students at Government Senior Secondary School, Lamingo, Jos North L.G.A. A sample size of one hundred was determined using Yaroyamene's formula; probability sampling techniques were adopted; questionnaires were used as an instrument for collecting data. The data collected were analysed using a simple table and percentage. This study revealed that $80 \%$ of peer group like all their friends, $75 \%$ don't lack selfconfidence among their peers, $60 \%$ have been sent out of the class before, 65\% agreed that influence on behaviour lower academic performance. The hypothesis was tested using chi-square, which showed no association between peer group pressure and the academic performance of adolescent students. Therefore, this research recommends that teachers with support from parents provide adequate guidance and intervention program to adolescents to help them understand how the friends they keep can positively or negatively influence their academic performance in school.
\end{abstract}

Keywords: Academic performance, Adolescent students, Peer group pressure, Government School, Truancy

\section{INTRODUCTION}

The basis of a child's education begins at home. This begins with informal education, which starts with the parents, especially the mother. The child will then be sent to school for final education where he will be exposed to so many people like the teachers, classmates, and school environment. all these people associated with the teaching of the child certainly influence the academic performance of the child greatly because he spends most of his time with them. As a result, the peer group is the first social group outside the home where the youngster tries to earn approval and recognition.

Smart \& Smart (2000) defined peer group as friends of about the same class of society, such as school classmates, boys scout, girls guide, chorister, football team, and social child. Each of these peer groups has its code of behaviour, which may or may not adhere to the advanced standard. Even very young children build a sense of self through their perceptions of essential individuals in their environment, such as family, teachers, and peers; the peer group becomes an agency of enculturation and learning. As a youngster grows older, his peer group or partner is likely to become more important to him than his parents or instructors, according to Derville (2001).

Peer group pressure also influences the development of children socializing skills. These early friendships help children learn to negotiate and relate to others, including their siblings and other family members. They learn from a peer how to cooperate and socialize according to group norms and group-sanctioned modes of behaviour. What a youngster value, know, wear, eat, and learn may influence their peers.

Wentzel (1989) and Lingrett (1995) discovered that as children get older and enter adulthood, their participation with and effect of peer identification grows, while the family's modeling value declines. During early life, peer modeling often replaces the modeling value of the domestic setting. Students are under a certain level of 


\section{DOI: $10.51386 / 25815946 /$ ijsms-v4i6p114}

pressure due to the social recognition they want, which motivates them to follow peer convictions or rejections. These peer groups on students, especially during adolescents and early adulthood, are a powerful force that influences academic performance. This is supported by Caltern (1998) findings, which states that a strong relationship exists between school adjustment behaviour and peer acceptance. It also found that quality and robust peer associations are related to poor or good academic performance and successful school transition. For example, suppose students are friends with secondary school dropouts. In that case, they tend to be absent from school, have a lower grade, and have been less popular and less likely to plan to attend higher education institutions because they have fewer positive opinions regarding school. If a dropout keeps in touch with friends who have remained in school, these people may be able to offer moral support in the case of a return to school. This shows a clear indication that the attitude and aspiration of peers and peer expectations and standards affect an individuals' efforts and achievement in school for many secondary school students.

Finally, the impact of peer group pressure on secondary school student's academic achievement cannot be overstated. This is because it is the foundation upon which the kid learns a great deal about their attitude, physical and social surroundings, and the development of skills and value for a better future.

These findings will aid parents, school counselors, and others responsible for our children's education in understanding the pattern of peer influence and how to prevent its potentially detrimental impacts.

\section{LITERATURE REVIEW}

According to Alvin (1982), the term peer group implies that members of the group are on the same level, which means that one's employee (for example a house boy, maid) is usually not members of one's peer group, but two employees working for the same company may be members of the same group people of the same age associate together and move through developmental stages with the same role expectation. The effect of age grades is strong in primary school because, most of the pupils know each other, or are either from the same ethnic or cultural background. In the primary school setting classroom heightens the effects of age grades because children are separated according to age, bringing several the same age together. Most of them remain together in the same group through the elementary school, forming and increasing cohesive bond with each passing year.

According to Oladele (1966), the peer groups is the first social groups outside the home in which the child attempts to gain acceptance each peer group has its code of conduct, which does not always conform to adult standard. The important thing is that each child takes its membership of the peer group very unacceptable to the group. Lack of acceptance by peer group is disturbing the child especially at adolescent age. Some children have been known to do badly in schools, not because they don't have the academic ability to do well, but because they are disturbed by the fact that they are not fully accepted by their peer group. The children regard the peer group as a social setting in which he can learn without undue interference from the adult community. What makes learning comparatively easy in the peer group is the fact that the child has equal status with the other children. There is an atmosphere of freedom in which each child easily learns the way of the world from others knowledge comes unsolicited in a friendly atmosphere. The peer group thus, become more and more important to achieve recognition, other ways the peer group can be of help to the child include teaching him the culture of the wider society, making possible social mobility, providing opportunity for the child to play many social roles, such as that of learning, follower, teacher or students. The peer group also helps the child to win his independence early from adult domination and sets before him goals, which is more easily attainable than the expectation of adults. This chapter has been divided into six parts for the purpose of easy understanding.

1. formation of peer group

2. self-concept

3. social/family factors

4. peer influence

5. the social achievement of the peer group

6. peer role in socialization

\section{FORMATION OF PEER GROUP}

The formation of peer groups follows a certain pattern. In early childhood, parents are important adults in a child life. According to Stan-Salazar (2005), peer groups are formed for different reason for example, if the peer group is formed for the purpose of friendship, then it will generally serve to provide a sense of belonging 


\section{DOI: $10.51386 / 25815946 /$ ijsms-v4i6p114}

together with social and emotional support for the group members. Some groups are formed to promote academic achievement among its members while others may promote oppositional identity by encouraging its group's members to go against the school rules and regulations or the school establishment in general.

According to Fafunwa (1979), a peer group comes into being because its members have common goals, interests, and motivations. Age groups in many ethnic societies in Nigeria have been used either for community development, educational purposes, and citizenship training in general or for purely political activities. According to Scott (1970), a peer group fixes its values and codes of conducts, which are then followed by individual members. The group decides what objectives and what goals are to be preferred over others and then define what means are acceptable for pursuing these goals. Ascribed factors like sex, age, social status or ethnicity helps to determine membership in most groups for example, and girls may identify with a peer group of girls; it is this group which is likely to serve them as reference group because of their sex roles. Children, who schools in Nigeria are most likely to associate first with those who come from the same area, speak the same local language and have common factors in common. According to Holander (1971), school children do not rush to form groups. They observe and evaluate one another before they form a formal peer group. In countries where adolescents come to school from variety of background, they remain strangers to each other for quite a long time before they get to know each other well enough to develop group norms.

According to Horton Cooley one of the first American sociologists who introduce the notion of secondary groups was in (1909), the secondary group was presented as having a face-to-face relationship marked by among of cooperation performance and intimacy. The groups possess some feelings of belonging. The face-toface aspect suggests that the group is small. Cooley identified only a few groups that fit his definition. The family, the play groups of children, and the neighbourhood or community group of elders in such a group individual enjoys a warm and seemingly unstructured existence. It is groups in which we can relax just hang out and do what we want to do within these primary groups. People learn the way and therefore social living. According to Godwin (1965), peer groups are undoubtedly useful in many aspects such as giving children from different families the opportunity to mix and by so doing broaden the scope of friendship.

Mixing with peer group is a good preparation for the future because one cannot but mix with other in later life. Those fail to mix well in their earlier life will be unable to mix well in future. The child interaction with other children and teachers from various background and with new problems and concepts enables him to modify or change his behaviour, attitudes and modification, peer groups give the child the opportunity to grow and depend less on family authority, to grow here means getting mature be able to take decision and accept their outcomes. Peer group is a form for receiving information of new knowledge. When children come together like that they later interact and talk. The peer group teach sex role by mixing with other boys and girls. They learn how trailing for a stable courtship and marriage. Peer group teaches unity, tolerance, and collective behaviour. As a group, they learn the spirit of living and let live and see themselves as group acting in union and having one voice.

\section{SELF CONCEPT FACTOR}

Self-concept results from the subject internalization of his social image. It is developed from different interaction with the social context and agent; great importance assigned to acceptance or rejection from other especially significant others. According to one researcher, Marsh parker and Smith, who propose a hierarchical and multifaceted model of self-concept in which there exist one general factor and several special one the later including academic self-concept? According to Sonchez (2002), "academic self" concept is at the base of future school success or failure. Having been formed starting schooling early childhood education from peer contact and teacher attitude and expectation. According to Edward (2002), self-concept was found to better predict performance than variables such as age or students' gender. According to Zsolnail (2002), said that self-concept influence performance indirectly by means of its influence on intrinsic motivation. According to Gonzailex (2002) in his research show it by means of an analysis of structural equations, how self-concept related casually to performance, but not vice-versa.

According to Nunez (1989), in his view find that the greater the student's self-concept more learning strategies will be uses facilitating deep information processing. According to Fullana (1995) study indicates positive selfconcept as one risk reducing factors against academic failure in the case of unfavourable family situations. 


\section{DOI: $10.51386 / 25815946 /$ ijsms-v4i6p114}

According to Perez (1998), using a casual explicative model emphasize that academic self-concept directly influences the global performance of the students.

\section{SOCIAL/FAMILY FACTORS}

The educational condition attributed to the family is beyond all doubt as there is an ever-increasing awareness of the importance of the parent's role in the progress and education development of their children. According to Adell, (2002), family background is the most important and most weighty factor in determining the academic performance attained by the students. Among family factors, of greater influenced are social class variable and the educational and family environment. Regarding socio class relevant research tells us that one's result and expectations for the future are better than the higher one belongs to the social ladies. One of the latest, studies carried out on performance in secondary schools in Spain. According to Martin (2002), upper class students show a better use of mutate cognitive strategies that those of a lower social class. Liorente (1990), mentioned that the influence of social class is mediated by cultural level which in turn determines family expectations, values, and attitudes regarding education. In other words, motivation to achieve depends more on the parent's level of learning than on their income. Castejon \& Perez (1998) in their view remarked that the child perception of family support directly affects performances while the mother level of studies does so indirectly.

Other researchers indicate that the most influential family components on performance are not socio-culture or economic but rather those pertaining to the effective or psychological dimension that is although good academic prepares the parents especially the mother and a positive cultural environment, favour scholastic performance. It is effective and relational variables which most stands out as factors in performance.

\section{PEER INFLUENCE}

Peer group influence on the child's development occurs by similar mechanism as those used by adults. Reinforcement, modeling and direct teaching and skills interaction with peer also promotes acquisition of social competencies such as controlling aggressive impulses and the expression of pre-socio behaviour. According to Adeole (2007), each extensive interaction with other ultimate relationship develops and by these conflicts important attitude and values are formed. Mush Grave has the view that in the family or school, the child is in a state of sub-service. While the school or family is composed of heterogeneous age group. The peer group is made up of homogenous age. The implication is that the things that cannot be taught in the family or school are learnt by children from the peers, fashion, dress, and mode of reading and educational information (etc) are gotten from peers. Leadership position among peers is achieved rather than ascribed; intellective leadership, physical strength success in sport(etc) are all achieved status. An attractive and self-assures students are easily accepted as a peer and students do this in order to belong. Certain standard are set by the group as norms and values. This peer pressure is associated in adolescents of all ethnic and racial background with risk behaviours such as truancy, drug Abuse, sexual activity again peer strength than do family values the level of teenage alcohol use.

According to Castejon, \&Perze (1998) in relation to academic performance, the socio-metric status of the students influences performance both directly and indirectly since it is influenced by intelligence. Other research also shows that positive correction exists between performance and peer relationship. Buote (2002) supported this statement and Montero (1990), added by saying that students failures in school are those most rejected by their group. In examine the effect of peer group pressure on academic performance of students in Government Secondary School Lamingo, Jos North Local Government Area; the researcher also consulted some authorities who have dealt extensively with these issues.

According to Mrs. J.J. Magdalene, a teacher in Government Secondary School in Jos North Local Government Area in Lamingo, said that students are influence by their peers positively, to my understanding some joined their peers to the library to read and make research when they were given assignment by their class teacher in school and they asked question and answer it within themselves and from this the slow learners gain from their peers and performed very well academically during examinations and classroom assessment having gain from their peer some knowledge, bringing good result in their academic performance, this comment supported that there could be positive influence and negative and so it is in two ways. 


\section{DOI: $10.51386 / 25815946 /$ ijsms-v4i6p114}

Young people claim to have negative habits of smoking, excess use of alcohol, sex, gambling, and drugs(etc) at the early age because of students. As some of these young people grow older, the influence of parents' waves, a desire to be popular and to be accepted by peer grows. Watch tower (2002), maintained that as some youths get older, the influence of parent's wanes and a desire to be popular and to be accepted by peers who grow strong. Others simply feel a need to talk with some who understand or who will make them feel loved or needed to be done by all that are concerned. These comments from the research have help to understand that peer group pressure influence academic performance in two ways positive and negatively.

From the above comment mentioned, the researcher strongly feels that everybody must work together. Parents, teachers, guardians, government(etc) should try to realize the importance of guidance and counselling to help the children on the need to choose a good association that will put them on the positive side and when this is done students' academic performance will improve positively for their future benefit.

\section{THE SOCIAL ACHIEVEMENT OF PEER GROUP}

According to Lippitt, \&White (1985), not all adolescent leaders are academically talented; there is none acceptance by ones peer since next young people to succeed in school, and high status is awarded to those who get good grades. The way good grades are attained is also important for those who get ' $A$ ' by cheating are not respected, non are those who perceived as trying to gain unfair advantages with the teacher. The student who is considered book worm may not have a high level of social status as the one who gets good grades with an average amount of effort.

According to Bichlen, \& Roberts (1974), the recognition the teacher gives to students with high achievement can either help their standing with their peer or it can be detrimental depending partly on the way the recognition is given. Some students do not want to be helped up as an example for other students, for that seems to isolate the students that are singled out. On the other hand, students who are held in high regard by the teacher are more likely to be admired by their peer than those whom the teacher criticizes. Perhaps the ideal position from the standing of students is to excel in classroom and remain one of the groups in which other students can evaluate the students as like rest of us.

Peers tend to influence each other on matter pertaining to success, power, prestige, respect, way of communicating with others and behaviour. Through these interactions they learn how to relate to others at different levels. Gronlund (1959) said that the improved moral derived from satisfying social relationship in the classroom helps create in the pupils a favourable attitude towards school in general.

\section{PEER ROLE IN SOCIALIZATION}

In all societies since the beginning of time, adolescents have learned to become adults by observing, limiting, and interacting with grown up around them. The self is shaped and honed by feedback from me and women who already know who they are and can help the young person find out who he or she is going to be. The importance of the family immediate and extended in an adolescent's life (in any life, for that matter) is of paramount importance. It is therefore quite starting and very distressing when we look around our society and see little time today teenagers spend in the company of adults.

The adolescent's today is socializing more within the confines of their peer than with any adults a situation that both parents and teachers fear and distrust because it competes with adult socializing experiences for the teenager's attention. According to Allen (1971), peer contributes to our socialization three respects. Firstly, peer offers a kind of companionship; attention and good will that parents cannot supply in return for behaviour like skill at games with parents are indifferent to.

Secondly, to the extent that peer group include children of slightly different ages and skill levels children can find models for what they will be soon. Adults are models for the very distant future. Thirdly, the contribution of the peer groups is that it gives children a chance to develop close relationship of their own choice peer group in other words are the place where we begin to become independent of our parents, a place where we develop standards for judging ourselves quite separate from those of the adult world. 


\section{DOI: $10.51386 / 25815946 /$ ijsms-v4i6p114}

According to Larson (1984), adults are afraid that the lives of their sons and daughters will be shaped by their peers and the culture they have built for themselves, knowing this adult themselves especially in today's selfcentred society, are prepared to invest relatively little or their own time, attention, and wisdom to provide the bridge. Except by parent's manipulation through external rewards and punishment, teenagers are more or less left on their own to choose among the directions available to them. In essence, it is other people who socialize us by the support and feedback they provide. George (1934) pointed out it is by relating to others either concretely or in imagination, that we develop attention pattern we call the self. According to Steinberg (1996), how much time one spends with friends as opposed to adults will play a great part in the development of the adolescents into the mature adult they will become someday.

According to Kaplan (1993), peer group membership answers adolescents' concerns about many things including their changing bodies and discussing their fears with other young people experiencing similar physical changes and asking similar questions about their impact helps adolescents to accept their physical development. Larson (1984) said that social structure is passed on through then family and the influence of the family sustains if time and energy is spent by both parents and teenagers towards a common set of goals leading to a climate of love and mutual support. When parents and children cease to pay attention to each other's goals, there is breakdown which is what is happening in society today. As long as the child lives in the limited environment of his home, he is influenced by his parents and siblings. In polygamous families and extended family systems as those which operate in Nigeria, the environment is greatly enlarged by comparison to the nuclear families. In large families' members other than parents and siblings also become models for imitation.

According to Mussen (1973), parental influence is more powerful than peer influence among adolescents whose parents' express affection, interest, understanding and willingness to be helpful. Thus, the parents continue to provide a highly personal and emotionally involved relationship which may be characteristics of peer group influence. Conclusively, Burro (1964) in his contributions as to the role of peer group in social changes quoted that social change is a process whereby some modification occurs in the society. This change can be large or small, gradual or rapid, violent or peaceful. Sociologists are concerned with low process of change works. So far, we have found that society generally moves from the simple to complex and that technology is an important force in this alternation. The speed of change is also an important question. Evaluation is a slow process. When people desire changes because of dissatisfaction with societal conditions, they may resort to revolution. Revolution is spurned by political, economic, and cultural conditions.

However, we are not sure of the exact cause of revolution. Social changes are a continuous process which is very similar to a widening stream that makes its way to the mouth of the river. It is very difficult to chart its path is speed up in place and slowdown in others. In some places the water is claim, in others ranging. Social change through peer group is very much like that. Its rate is not constant, by studying this phenomenon over the years, sociologist is beginning to chart the cure of this historical view like the behavioural outcomes of a child who interest with the group that is either educationally inclined or otherwise. In generally conclusion, most peer groups start in primary school in the form of best friends, alter as they move into the adolescent stage, they tend to form cliques and crews.

Peer groups are an important part of adolescent's life as it reflects their desire for autonomy and their preparation towards adulthood. Peer groups have different function for friendship, sense of belonging and presocial functions which are important in the development of the child's social, emotional, and cognitive development.

\section{METHODOLOGY AND METHODS}

This study utilized the quantitative method research design with a questionnaire to extract information from the respondents. The data gathered was treated statistically using frequency count and percentage was utilized. The population for this study was 134 which consist of the secondary school students in G.S.S.S Lamingo, Jos North Local Government Area of Plateau State and they were made to respond to the questions drawn on the questionnaires. The instrument for the collection of data used in this study was the use of questionnaire. The set of questions were carefully written to accommodate the purpose of the study. The examinations of these questions before administering them were done to reduce type 1 error. 
DOI: $\underline{10.51386 / 25815946 / \mathrm{ijsms}-\mathrm{V} 4 \mathrm{i} 6 \mathrm{p} 114}$

Volume: 4 Issue: 6

November to December 2021

https://www.ijsmsjournal.org

\section{RESULTS AND DISCUSSION}

This chapter deals with the analysis of the data collected using simple percentage using the items in the questionnaire. The two demographic characteristics of respondents were studied. These were age and gender.

Table 1: Do you like all your friends

\begin{tabular}{|l|l|l|l|l|l|l|}
\hline \multirow{2}{*}{ Options } & \multicolumn{2}{|c|}{ Gender } & \multirow{2}{*}{ Total (\%) } & \multicolumn{2}{|c|}{ Age Range } & $\begin{array}{l}\text { Total } \\
(\%)\end{array}$ \\
\cline { 2 - 4 } & Female (\%) & Male (\%) & & $0-15 y$ yrs (\%) & $\begin{array}{l}16 \text { \& above } \\
\text { years (\%) }\end{array}$ & \\
\hline Yes & $28(28 \%)$ & $37(37 \%)$ & $65(65 \%)$ & $40(40 \%)$ & $35(35 \%)$ & $75(65 \%)$ \\
\hline No & $17(17 \%)$ & $18(\%)$ & $35(35 \%)$ & $15(15 \%)$ & $10(10 \%)$ & $25(25 \%)$ \\
\hline Total & $45(45 \%)$ & $55(55 \%)$ & $100 \%$ & $55(55 \%)$ & $45(45 \%)$ & $100 \%$ \\
\hline
\end{tabular}

Table 1 above shows gender distribution of the respondents, $65(65 \%)$ answered YES that they like all their friends, Female had 28 (28\%), while Male had 37 (37\%).35 (35\%) Answered No; Female had 17(17\%), while Male had 18(18\%). Also in age range, 75(75\%) answered Yes, 40(40\%) fall under 0-15 years old, while 35(35\%) fall under 16 and above years old. 25(25\%) answered NO,15(15\%) falls under $0-15$ years old, while $10(10 \%)$ fall under 16 and above years old.

Table 2: Stay with your friends late

\begin{tabular}{|l|l|l|l|l|l|l|}
\hline \multirow{2}{*}{ Options } & \multicolumn{2}{|c|}{ Gender } & \multirow{2}{*}{ Total (\%) } & \multicolumn{2}{|c|}{ Age Range } & \multirow{2}{*}{$\begin{array}{l}\text { Total } \\
\end{array}$} \\
\cline { 2 - 5 } & Female (\%) & Male (\%) & & $0-15(\%)$ & 16 \& above (\%) & \\
\hline Yes & $30(30 \%)$ & $30(30 \%)$ & $60(60 \%)$ & $25(25 \%)$ & $40(40 \%)$ & $65(65 \%)$ \\
\hline No & $22(22 \%)$ & $18(\%)$ & $40(40 \%)$ & $20(20 \%)$ & $15(15 \%)$ & $35(35 \%)$ \\
\hline Total & $52(52 \%)$ & $48(48 \mathrm{~s} \%)$ & $100 \%$ & $45(45 \%)$ & $55(55 \%)$ & $100 \%$ \\
\hline
\end{tabular}

From the information of Table 2 above shows gender distribution of the respondents, $60(60 \%)$ answered Yes that they stay with their friends late; Female had 30 (30\%), while Male had 30 (30\%).40 (40\%) Answered No they don't stay with their friends lately; Female had 22(22\%), while Male had 18(18\%). Also in age range, $65(65 \%)$ answered Yes, $25(25 \%)$ fall under 0 - 15 years old, while 40(40\%) fall under 16 and above years old. $35(35 \%)$ answered NO, 20(20\%) fall under $0-15$ years old, while $15(15 \%)$ fall under 16 and above years old.

Table 3: Lack self confidence among your peers

\begin{tabular}{|l|l|l|l|l|l|l|}
\hline \multirow{2}{*}{ Options } & \multicolumn{2}{|c|}{ Gender } & Total (\%) & \multicolumn{2}{|c|}{ Age Range } & \multirow{2}{*}{ Total (\%) } \\
\cline { 2 - 3 } & Female (\%) & Male (\%) & & $0-15(\%)$ & $16 \&$ above (\%) & \\
\cline { 5 - 7 } & & & & & & \\
\hline Yes & $25(25 \%)$ & $11(11 \%)$ & $36(36 \%)$ & $30(30 \%)$ & $6(6 \%)$ & $36(36 \%)$ \\
\hline No & $34(34 \%)$ & $30(30 \%)$ & $64(64 \%)$ & $36(36 \%)$ & $28(28 \%)$ & $64(64 \%)$ \\
\hline
\end{tabular}

From Table 3 above shows that gender distribution of the respondents, $36(36 \%)$ answered Yes, they lack self confidence among their peers; Female had 25 (25\%), while Male had 11 (11\%). 64 (64\%) Answered No they do not lack self confidence among their peers; Female had 34(34\%), while Male had 41(41\%). Also in age range, $36(36 \%)$ answered Yes, 30(30\%) fall under 0 - 15 years old, while 6(6\%) fall under 16 and above years old. $64(64 \%)$ answered NO, 36(36\%) fall under 0 - 15 years old, while 28(28\%) fall under 16 and above years old. 
DOI: $\underline{10.51386 / 25815946 / \mathrm{ijsms}-\mathrm{V} 4 \mathrm{i} 6 \mathrm{p} 114}$

Volume: 4 Issue: 6

November to December 2021

https://www.ijsmsjournal.org

Table 4: Feeling insecure among your family members

\begin{tabular}{|l|l|l|l|l|l|l|}
\hline \multirow{2}{*}{ Options } & \multicolumn{2}{|c}{ Gender } & \multirow{2}{*}{ Total (\%) } & \multicolumn{2}{c|}{ Age Range } & \multirow{2}{*}{ Total (\%) } \\
\cline { 2 - 3 } \cline { 5 - 6 } & Female (\%) & Male (\%) & & $0-15(\%)$ & $16 \&$ above (\%) & \\
\hline Yes & $28(28 \%)$ & $14(14 \%)$ & $42(42 \%)$ & $30(30 \%)$ & $12(12 \%)$ & $42(42 \%)$ \\
\hline No & $25(25 \%)$ & $33(33 \%)$ & $58(58 \%)$ & $30(30 \%)$ & $28(28 \%)$ & $58(58 \%)$ \\
\hline Total & $53(53 \%)$ & $47(47 \%)$ & $100 \%$ & $60(60 \%)$ & $40(40 \%)$ & $100 \%$ \\
\hline
\end{tabular}

From Table 4 above shows that gender distribution of the respondents, $42(42 \%)$ answered Yes, they feel insecure among their family members; Female had 28 (28\%), while Male had 14 (14\%). 58 (58\%) Answered No they do not feel insecure among their family members; Female had 25(25\%), while Male had 33(33\%). Also in age range, $42(42 \%)$ answered Yes, 30(30\%) fall under 0 - 15 years old, while 12(12\%) fall under 16 and above years old. 58(58\%) answered NO, 30(30\%) fall under $0-15$ years old, while 28(28\%) fall under 16 and above years old.

Table 5: Have you been sent out of the class before

\begin{tabular}{|l|l|l|l|l|l|l|}
\hline \multirow{2}{*}{ Options } & \multicolumn{2}{|l|}{ Gender } & Total (\%) & \multicolumn{2}{l|}{ Age Range } & \multirow{2}{*}{ Total (\%) } \\
\cline { 2 - 3 } & Female (\%) & Male (\%) & & $0-15(\%)$ & 16 \& above (\%) & \\
\hline Yes & $28(28 \%)$ & $43(43 \%)$ & $71(71 \%)$ & $30(30 \%)$ & $37(37 \%)$ & $67(67 \%)$ \\
\hline No & $11(11 \%)$ & $18(18 \%)$ & $29(29 \%)$ & $12(12 \%)$ & $21(21 \%)$ & $33(33 \%)$ \\
\hline Total & $39(39 \%)$ & $61(61 \%)$ & $100 \%$ & $42(42 \%)$ & $58(58 \%)$ & $100 \%$ \\
\hline
\end{tabular}

From Table 5 above shows that gender distribution of the respondents, $71(71 \%)$ answered Yes, they have been sent out of class before; Female had 28 (28\%), while Male had 43 (43\%). 29 (29\%) Answered No they have not been sent out of class before Female had 11(11\%), while Male had 18(18\%). Also in age range, 67(67\%) answered Yes, 30(30\%) fall under 0 - 15 years old, while 37(37\%) fall under 16 and above years old. 33(33\%) answered NO, 12(12\%) fall under $0-15$ years old, while $21(21 \%)$ fall under 16 and above years old.

Table 6: Association with the peer group can make the students to become a truant and reduce the academic performance of the children

\begin{tabular}{|c|c|c|c|c|c|c|}
\hline \multirow[t]{2}{*}{ Options } & \multicolumn{2}{|l|}{ Gender } & \multirow[t]{2}{*}{ Total (\%) } & \multicolumn{2}{|l|}{ Age Range } & \multirow{2}{*}{$\begin{array}{l}\text { Total } \\
(\%)\end{array}$} \\
\hline & Female (\%) & Male $(\%)$ & & $0-15(\%)$ & $16 \&$ above $(\%)$ & \\
\hline Yes & $60(60 \%)$ & $36(36 \%)$ & $96(96 \%)$ & $76(72 \%)$ & $20(20 \%)$ & $\begin{array}{l}96 \\
(96 \%)\end{array}$ \\
\hline No & $2(2 \%)$ & $2(2 \%)$ & $4(4 \%)$ & $3(7 \%)$ & $(1 \%)$ & $\begin{array}{l}4 \\
(4 \%)\end{array}$ \\
\hline Total & $62(62 \%)$ & $38(38 \%)$ & $100 \%$ & $79(79 \%)$ & $21(21 \%)$ & $100 \%$ \\
\hline
\end{tabular}

Table 6 above shows that gender distribution of the respondents, $71(71 \%)$ answered Yes that association with peer group can make the students to become truant and reduce the academic performance of students; Female had 60 (60\%), while Male had 36 (36\%). 4 (4\%) Answered No that Association with the peer group cannot make the students to become a truant and reduce the academic performance of the children; Female had 2(2\%), while Male had 2(2\%). Also in age range, 96(96\%) answered Yes, 76(76\%) fall under 0 - 15 years old, while $20(20 \%)$ fall under 16 and above years old. 4(\%) answered NO, 3(3\%) fall under $0-15$ years old, while 1(1\%) fall under 16 and above years old. 


\section{DOI: $10.51386 / 25815946 /$ ijsms-v4i6p114}

Volume: 4 Issue: 6

November to December 2021

https://www.ijsmsjournal.org

Table 7: Lateness to school which lower academic performance are encouraged by peer group activities

\begin{tabular}{|l|l|l|l|l|l|l|}
\hline \multirow{2}{*}{ Options } & \multicolumn{2}{|l|}{ Gender } & Total (\%) & \multicolumn{2}{l|}{ Age Range } & \multirow{2}{*}{ Total (\%) } \\
\cline { 2 - 3 } & Female (\%) & Male (\%) & & $0-15(\%)$ & $16 \&$ above (\%) & \\
\hline Yes & $50(50 \%)$ & $28(28 \%)$ & $86(86 \%)$ & $56(56 \%)$ & $25(25 \%)$ & $81(81 \%)$ \\
\hline No & $15(15 \%)$ & $7(7 \%)$ & $14(14 \%)$ & $11(3 \%)$ & $8(8 \%)$ & $19(19 \%)$ \\
\hline Total & $65(65 \%)$ & $35(35 \%)$ & $100 \%$ & $67(67 \%)$ & $33(33 \%)$ & $100 \%$ \\
\hline
\end{tabular}

Table 7 above shows that gender distribution of the respondents, $86(86 \%)$ answered Yes that Lateness to school which lower academic performance are encouraged by peer group activities; Female had 50 (50\%), while Male had 28 (28\%). 14 (14\%) Answered No that Lateness to school which lower academic performance are not encouraged by peer group activities; Female had 15(15\%), while Male had 7(7\%). Also in age range, 81(81\%) answered Yes, 56(56\%) fall under 0 - 15 years old, while 25(25\%) fall under 16 and above years old. 19(19\%) answered NO, 11(11\%) fall under $0-15$ years old, while 8(8\%) fall under 16 and above years old.

In table 1 above, the gender distribution of the respondents, $65(65 \%)$ answered YES that they like all their friends; Female had 28 (28\%), while Male had 37 (37\%).35 (35\%) Answered No; Female had 17(17\%), while Male had 18(18\%). Also in age range, 75(75\%) answered Yes, 40(40\%) fall under 0-15 years old, while 35(35\%) fall under 16 and above years old. 25(25\%) answered NO,15(15\%) falls under $0-15$ years old, while 10(10\%) fall under 16 and above years old.

From the information in table 2 above, for gender distribution of the respondents, $60(60 \%)$ answered Yes that they stay with their friends late; Female had 30 (30\%), while Male had 30 (30\%).40 (40\%) Answered No they don't stay with their friends lately; Female had 22(22\%), while Male had 18(18\%). Also in age range, 65(65\%) answered Yes, 25 (25\%) fall under 0 - 15 years old, while 40(40\%) fall under 16 and above years old. 35 (35\%) answered NO, 20(20\%) fall under $0-15$ years old, while 15(15\%) fall under 16 and above years old.

According to table 3 above of the gender distribution of the respondents, $36(36 \%)$ answered Yes, they lack self confidence among their peers; Female had 25 (25\%), while Male had 11 (11\%). 64 (64\%) Answered No they do not lack self confidence among their peers; Female had 34(34\%), while Male had 41(41\%). Also in age range, $36(36 \%)$ answered Yes, 30(30\%) fall under 0 - 15 years old, while 6(6\%) fall under 16 and above years old. $64(64 \%)$ answered NO, 36 (36\%) fall under 0 - 15 years old, while 28(28\%) fall under 16 and above years old. Also, in table 4above for gender distribution of the respondents, 42 (42\%) answered Yes, they feel insecure among their family members; Female had 28 (28\%), while Male had 14 (14\%). 58 (58\%) Answered No they do not feel insecure among their family members; Female had 25(25\%), while Male had 33(33\%). Also in age range, 42(42\%) answered Yes, 30(30\%) fall under 0 - 15 years old, while 12(12\%) fall under 16 and above years old. 58(58\%) answered NO, 30(30\%) fall under $0-15$ years old, while 28(28\%) fall under 16 and above years old.

Additionally, in table 5 above of the gender distribution of the respondents, $71(71 \%)$ answered Yes, they have been sent out of class before; Female had 28 (28\%), while Male had 43 (43\%). 29 (29\%) Answered No they have not been sent out of class before; Female had 11(11\%), while Male had 18(18\%). Also in age range, $67(67 \%)$ answered Yes, 30(30\%) fall under 0 - 15 years old, while 37(37\%) fall under 16 and above years old. $33(33 \%)$ answered NO, 12(12\%) fall under 0 - 15 years old, while 21(21\%) fall under 16 and above years old.

Furthermore, in table 6 above of the gender distribution of the respondents, $71(71 \%)$ answered Yes that association with peer group can make the students to become truant and reduce the academic performance of students; Female had 60 (60\%), while Male had 36 (36\%). 4 (4\%) Answered No that Association with the peer group cannot make the students to become a truant and reduce the academic performance of the children; Female had 2(2\%), while Male had 2(2\%). Also in age range, 96(96\%) answered Yes, 76(76\%) fall under 0 - 15 years old, while 20(20\%) fall under 16 and above years old. 4(\%) answered NO, 3(3\%) fall under $0-15$ years old, while $1(1 \%)$ fall under 16 and above years old. 


\section{DOI: $10.51386 / 25815946 /$ ijsms-v4i6p114}

Meanwhile, in table 7 above of the gender distribution of the respondents, 86 (86\%) answered Yes that Lateness to school which lower academic performance are encouraged by peer group activities; Female had $50(50 \%)$, while Male had 28 (28\%). 14 (14\%) Answered No that Lateness to school which lower academic performance are not encouraged by peer group activities; Female had 15(15\%), while Male had 7(7\%). Also in age range, $81(81 \%)$ answered Yes, 56(56\%) fall under 0 - 15 years old, while 25(25\%) fall under 16 and above years old. $19(19 \%)$ answered NO, 11(11\%) fall under 0 - 15 years old, while 8(8\%) fall under 16 and above years old.

\section{CONCLUSIONS AND RECOMMENDATION}

\section{A. Conclusion}

Based on the finding, it has been discovered that peer group pressure is in two ways, both negative and positive. There are ways the teacher could help these students of peer to avoid serious influence since students develop negatively and this could after their academic performance. it was also discovered that peer influence is not always bad. The fact that many students have confidence in their friends show also that they could be helped in terms of studies when they are together especially boys, and they help them to grow in knowledge and improve academically.

\section{B. Recommendations}

In line with the findings in the study, the researchers recommend the following:

There should be an intervention program for the students which will help and expose them to resist negative peer pressure and accept the positive peer pressure. One of the best is known is the (Drug Abuse Resistance Education), this enables them to resist the pressure to use drugs and alcohol.

Teachers should use their teaching periods to teach and help these peers so that peer pressure will not damage their future life.

Parents should help their children financially so that they will not because of money follow bad gangs and Parents should also find about their children emotional needs because some children may not tell them problems but to their peers who is closer to them than their parents. This research work will serve as a stimulant to other scholars who may wish to carry out further research work on this area of study.

The researchers opinion in this research falls under the following area which will be of great benefit.

1. Negative effect associated with peer group.

2. The causes credited to high rate of peer influence or group.

3. A similar study on female academic performance be undertaken to compare the study.

\section{ACKNOWLEDGMENT}

The writers express their gratitude to the Almighty Father in Heaven. We were able to accomplish this study project thanks to several people's contributions, assistance, and direction. It would not be easy to include them all on this list. Nonetheless, their enormous peer review, expert evaluation, and the distribution of certain reading materials have contributed to the success. We were also grateful for the insightful comments offered by the anonymous peer reviewers at IJSMS Journal. The unselfishness and creativity of one and all have improved this research in innumerable ways and saved us from many errors, those that inevitably remain our entire responsibility. God bless you all.

Ethical Approval: Approval from National Teachers' Institute Kano Ethics Review Board was obtained to conduct the study.

Conflicts of interest: The authors declare no conflict of interest.

OrCID IDs: 0000-0002-3444-4713

0000-0002-0508-7729

\section{REFERENCES}

[1] Adell, M., A. (2002). Family Background, Most Important and Weighing Factors. (3 ${ }^{\text {rd }}$ Ed., Pp. 52- 59). Madrid publishers, Madrid.

[2] Adeole, J., Guardione, P., and Salagar, S. (2007). Formation of peer group. Journal of the youth and adolescent, 5:16 - 25.

[3] Allen, G. (1971). The Contribution of Peer Group to Socialization. (1 ${ }^{\text {st }}$ Ed., Pp. 51- 59). Elsevier publishers, Chicago. 


\section{DOI: $\underline{10.51386 / 25815946 / \mathrm{ijsms}-\mathrm{v} 4 \mathrm{i} 6 \mathrm{p} 114}$}

Volume: 4 Issue: 6

November to December 2021

https://www.ijsmsjournal.org

[4] Alvin, L., Smart, O., B., and Peer, G., O. (1982). The cohesive bond involvement in peer group. Journal of educational literature, 3 (2): $21-28$.

[5] Bichlen, W., L., and Roberts, K., L. (1974). The Social Motivation of Peer Group. (1 ${ }^{\text {st }}$ Ed.).(Pp 192 - 201).Pennsylvania publishers, New York.

[6] Buote, I. (2002). Students' failure: those rejected. International academic section of humanities and social sciences, 2: 59 - 70.

[7] Burro, C. (1964). Peer Group with Social Modification. ( $1^{\text {st }}$ Ed.).(Pp $\left.14-22\right)$. Revistra London press, London.

[8] Caltern, N., M. (1998). No strong relationship between school adjustment behaviour and peer acceptance. International Journal of Psychology, 4: 112 - 130.

[9] Castejon, J., and Perez, M. (1998). Socio-metric Status of Family Support. (2 ${ }^{\text {nd }}$ Ed., Pp 70 - 80). Revistra Bordon London Press, London.

[10] Derville, B, (2001). The Controversy between Peer Group, Teachers and Parents. ( $3^{\text {rd }}$ Ed., Pp 45 - 56). Tesina Universal Pontilucia De Sclamanca, Tesina.

[11] Edward, B., O. (2002). Self-concept of student gender. Article of educational literature, 3: 69 - 73.

[12] Fafunwa, J., F. (1979). Peer group: its common goals, interests, and motivation. International Journal of psychology, 4 : 93 - 97.

[13] Fullana, N. (1995). Positive self-concept: one risk reducing factor against academic failure. Journal of educational psychology, 5: 34 -38 .

[14] George, M, (1934). Imagination of self-pattern attention. Article of self-education, 4: 2-5.

[15] Godwin, A., A. (1965). Peer groups: the scope of friendship. International Journal of Sociology, 8: 5 - 9.

[16] Gonzailex, P., Edward, B., O., and Zsolnail, F., O. (2002). The analysis of structural equation of self-concept. International Journal of sociology, 6 (2): $29-38$.

[17] Gronlund, B. (1959). Social Relationship in the classroom. (1 ${ }^{\text {st }}$ Ed., Pp. $\left.70-81\right)$. Revistra London press, London.

[18] Holander, A., L., Lumas, B., and Chingy, W. (1971). School Children and Their Formation of Peer Group. (1 ${ }^{\text {st }}$ Ed., Pp. 98 - 108). Elsevier publishers, Chicago.

[19] Horton, C. (1909). The Sociology among Secondary School groups. ( ${ }^{\text {st }}$ Ed., Pp. 32 - 38). Revistra press, Washington DC.

[20] Kaplan, C., T. (1993). Peer group membership among adolescents. International Journal of adolescents' relationship, $9: 19$ - 26.

[21] Larson, T., L. and Chingy, W. (1984). Peer group and culture. International Journal of relationship, 2 (4): 12 - 17.

[22] Lingrett, W. (1995). Modeling value of peer group. Journal of educational literature, 8: 39 - 48.

[23] Liorete, G. (1990). The Influence of Social class. ( $1^{\text {st }}$ Ed., Pp. 23 - 40). Tesina Universal Pontilucia De Sclamanca, Tesina.

[24] Lippitt, W., and White, R., K. (1985). The social achievement of peer group. International Journal of sociology, 1 (3): 92 - 97.

[25] Martin, E. (2002). Students Socio-cultural level. $\left(2^{\text {nd }}\right.$ Ed., Pp. 79 - 85). Madrid Institute Idea Publishers, Madrid.

[26] Mussen, K. (1973). Parental and Peer Group Influence among adolescents. ( ${ }^{\text {st }}$ Ed., Pp 43 - 55). Elsevier publishers, Chicago.

[27] Nunez, M., Pert, P., and Peinde, G. (1989). Students Self Concept Strategies. (1 ${ }^{\text {st }}$ Ed., Pp 132 - 145). Elsevier publishers, Chicago.

[28] Oladele, T. (1966). Peer group: the first social groups outside the home. Article of educational literature, 4 (1): 11 - 17.

[29] Perez, C., B. (1998). Effect of early friendship. ( ${ }^{\text {st }}$ Ed., Pp. 99 - 110). Madrid publishers, Madrid.

[30] Sanchez, B. (2002). Academic Self Concepts: School Success or Failure. (2 ${ }^{\text {nd }}$ Ed., Pp. 90 - 99). London Surgan press Ltd, London.

[31] Steinberg, S., O. (1989). Effect of Peer Group in the School. (1 ${ }^{\text {st }}$ Ed., Pp. 71 - 82). Elsevier publishers, Chicago.

[32] Scott, W. (1970). Value and code of conducts of peer group. Article of educational literature, 5 (3): 15 - 23.

[33] Smart, U., and Smart, A. (2000). The skills and potential of the students. International Literature of Education, 7(2): 19 - 29). 
DOI: $\underline{10.51386 / 25815946 / \mathrm{ijsms}-\mathrm{v} 4 \mathrm{i} 6 \mathrm{p} 114}$

Volume: 4 Issue: 6

November to December 2021

https://www.ijsmsjournal.org

[34] Stan-Salazar, P., Peer, G., O., and Oladele, T. (2005). The Importance of Peer Group. (1 ${ }^{\text {st }}$ Ed., Pp. 102 - 112). Madrid publishers, Madrid.

[35] Watch Tower (2002). Desire to Be Popular and Be Accepted. ( ${ }^{\text {rd }}$ Ed., Pp. 40 - 62). New York Watch Tower Bible and Tract Society of Pennsylvania, New York.

[36] Wentzel, E. (1989). Peer group identification with its modeling value. Article of educational literature, 5: 22 - 27.

[37] Zsolnail, F., O. (2002). Self-concept on intrinsic motivation. International Journal of educational literature, 4: 39 - 47. 